\title{
STRATEGI PEMBELAJARAN GUNA MENINGKATKAN KUALITAS BELAJAR SISWA MELALUI SARANA PRASARANA DI SD AL-MA'SOEM
}

\author{
Rakanita Dyah Ayu Kinesti, Naily Himmatul Ulya, Laana Nafisatus Suroyya, Fathia \\ Latifah, Eka Vina Rahmawati, Nurul Khoirin Nida, dan Aeni Khasanah \\ Institut Agama Islam Negeri Kudus, Jawa Tengah, Indonesia \\ Email: Rakanita@iainkudus.ac.id, nailyhimmatul8@gmail.com, laanasuroyya3@gmail.com, \\ fathialatifah14@gmail.com, ekafina9@gmail.com,nurulkhnida@gmail.com. \\ aenikhasanah30@gmail.com
}

\begin{tabular}{|c|c|}
\hline INFO ARTIKEL & RAK \\
\hline $\begin{array}{l}\text { Diterima } \\
2 \text { September } 2020 \\
\text { Direvisi } \\
15 \text { November } 2020 \\
\text { Disetujui } \\
15 \text { Desember } 2020\end{array}$ & $\begin{array}{l}\text { Strategi merupakan sebuah cara atau pendekatan yang sangat menyeluruh } \\
\text { dan sangat berkaitan dengan adanya pelaksanaan gagasan atau suatu } \\
\text { perencanaan serta eksekusi dalam suatu aktivitas yang berada dalam kurun } \\
\text { waktu tertentu. Dalam proses pembelajaran sarana dan prasarana sangat } \\
\text { diperlukan dalam rangka menunjang kelancaran proses kegiatanya, } \\
\text { sehingga pengelolaan sarana dan prasarana sangat diperlukan oleh setiap } \\
\text { sekolah. Tujuan penelitian ini untuk menjelaskan: (1) Strategi Peningkatan }\end{array}$ \\
\hline $\begin{array}{l}\text { Kata Kunci: } \\
\text { Peningkatan, } \\
\text { Kualitas, } \\
\text { Pembelajaran, } \\
\text { Sarana dan } \\
\text { Prasarana }\end{array}$ & $\begin{array}{l}\text { kualitas pembelajaran Di SD Al Masoem, (2) Perencanaan Peningkatan } \\
\text { Sarana dan Prasarana di SD Al Masoem, (3) Peran pendidik dalam } \\
\text { peningkatan kualitas pembelajaran melalui sarana dan prasarana di SD Al } \\
\text { Ma'soem. Penelitian ini menggunakan pendekatan kualitatif dengan } \\
\text { rancangan studi pustaka dan Studi Hasil Pengamatan. Teknik } \\
\text { pengumpulan data yang digunakan, meliputi: (1) observasi partisipan, (2) } \\
\text { wawancara mendalam, dan (3) studi dokumentasi.Dengan demikian dapat } \\
\text { disimpulkan bahwa Strategi Peningkatan Kualitas Pembelajaran melalui } \\
\text { Peningkatan Sarana dan Prasana terbukti efektif untuk meningkatkan hasil } \\
\text { belajar siswa yang merupakan hasil dari kualitas pembelajaran yang } \\
\text { diberikan dari pendidik kepada siswa di SD Al Masoem, Bandung, Jawa } \\
\text { Barat. }\end{array}$ \\
\hline
\end{tabular}

\section{ABSTRACT}

Strategy is a method or approach that is very comprehensive and closely related to the implementation of an idea or a plan and execution in an activity that is within a certain time. In the learning process, facilities and infrastructure are needed in order to support the smooth process of their activities, so that the management of facilities and infrastructure is needed by every school.The purpose of this study is to explain: (1) Strategies for improving the quality of learning at SD Al Masoem, (2) Planning for improving facilities and infrastructure at SD Al Masoem, (3) The role of educators in improving the quality of learning through Keyword: facilities and infrastructure at SD Al Ma'soem. This study uses a Improvement, qualitative approach with a literature study design and Observational Quality, Learning, Study. The data collection techniques used include: (1) participant Facilities and observation, (2) in-depth interviews, and (3) documentation studies. Thus, it can be concluded that the Strategy to Improve the Quality of 
Rakanita Dyah Ayu Kinesti, Naily Himmatul Ulya, Laana Nafisatus Suroyya, Fathia Latifah, Eka Vina Rahmawati, Nurul Khoirin Nida, dan Aeni Khasanah

\begin{tabular}{ll}
\hline Infrastructure. & Learning through Improvement of Facilities and Infrastructure is proven \\
to be effective in improving student learning outcomes which is the result \\
of the quality of learning provided by educators to students at Al Masoem \\
Elementary School, Bandung, West Java.
\end{tabular}

\section{Pendahuluan}

Pendidikan merupakan salah satu pendorong penting dalam hal kemajuan negara. Kualitas pendidikan yang baik akan mnciptakan struktural yang ada di negara tersebut menjadi teratur. Indonesia merupakan salah satu negara dengan tingkat pendidikan yang masih rendah jika dibandingkan dengan negara lain. Rendahnya pendidikan di Indonesia ini disebabkan oleh beberapa hal antara lain dari pendidik, peserta didik, pemerintah, fasilitas, orang tua, lingkungan. Dan sebagainya. Selain itu, tingkat sumber daya manusia juga harus dikembangkan. Hal ini dikarenakan sumber daya manusia saat ini sangat diperlukan dalam peningkatan kualitas pendidikan. Peningkatan kualitas Sumber Daya Manusia (SDM) dalam berbagai aspekdikehidupan ini merupakan faktor yang paling menunjang persaingan global yang terjadi di dunia. Era reformasi yang sedang berjalan sekarang ini telah memasuki pascareformasi yang diindikasikan dengan adanya perombakan dalam bidang politik, sosial, ekonomi, hamkam, dan moneter. Jika Sumber Daya Manusia (SDM) yang kita ciptakan berkualitas maka kita dapat bersaing dengan negara lain secara sehat dan profesional. Peningkatan kualitas SDM sangat berkaitan dengan pendidikan. Oleh karena itu, SDM menjadi faktor utama dalam peningkatan kualitas pendidikan terutama di Indonesia (Solikah, 2015).

Kualitas pendidikan sangat dipengaruhi oleh beberapa pihak antara lain dari siswa, orang tua, pemerintah, serta pendidik. Pihakpihak tersebut saling berkaitan dan sangat diperlukan untuk mewujudkan kualitas pendidikan yang terprogram dan menjadi lebih baik. peningkatan kualitas pendidikan memerlukan strategi yang tepat dalam penanganannya. Peningkatan kualitas pendidikan di Indonesia sangat berkaitan dengan terlaksananya proses pembelajaran di sekolah. Peningkatan kualitas ini memerlukan strategi atau kiat-kiat yang tepat dengan memanfaatkan sumber daya dari lembaga yang dimiliki. Ketika strategi dapat berjalan dengan terstruktur maka proses pembelajaran akan berjalan secara optimal, lancar dan teprogram. Dalam pendidikan strategi pembelajaran sangatlah penting dalam peningkatan mutu sekolah ataupun mutu pendidikan, hal ini karena strategi pembelajaran merupakan suatu kegiatan yang dilakukan guna memenuhi tujuan pembelajaran yang ingin dicapai. Kegiatan yang dilakukan secara terstruktur dan terorganisisasi diharapkan dapat berjalan dengan lancar sesuai dengan tujuan yang telah dirancang.

Berdasarkan hasil penelitian dari Jurnal Studi Keislaman berjudul Strategi Peningkatan Mutu Penididikan Di Sekolah menjelaskan bahwa strategi yang dilakukan di Madrasah Aliyah Hasan Jufri bertujuan untuk meningkatkan prestasi akademik serta pretasi non akademik. Pembagian strukturisasi dalam sekolah ini dilakukan di infrastruktur, serta perbaikan dilingkuan sekolah sehingga menjadi kondusif (Shobri, 2017). Sedangkan dalam Jurnal Sosial Humaniori berjudul Strategi Meningkatkan Mutu Penididikan Di Madrasah Aliyah Hasan Jufri menjelaskan bahwa strategi peningkatan mkualitas pendidikan terutama kualitas pembelajaran dilakukan dengan fokus tehaadap pendidik. Startegi yang dilakukan sekolah untuk peningkatan mutu pengajar adalah mengadakan kegiatan-kegiatan contohnya 
yaitu seminar, workshop, pelatihan dan sebagainya (Yana, 2019).

Dari hasil penelitian mengenai jurnal diatas tidak jauh beda dari hasil pengamatan, studi kasus dan juga penjelasan yang telah disampaikan oleh pemateri di SD ALMA'SOEM. Di sekolahan ini menjelaskan bahwa strategi peningkatan kualitas pendidikan terutama pembelajaran sama yang dilakukan di sekolah lain. Tambahan dari sekolahan ini yaitu mneningkatkan kualitas dari wali kelas, serta selain itu peratutan yang diterapkan di sekolahan ini dibuat secara ketat sehingga tingkat kedisiplinan peserta didik juga menjadi meningkat.

Penulisan artikel ini mempunyai beberapa tujuan yaitu pertama, untuk mengetahui strategi kualitas pembelajaran di SD AL MA'SOEM. Dalam pembahasan ini membahas tentang bagaimana strategi guru dalam peningkatan mutu pendidik sehingga motivasi belajar dari peserta didik menjadi meningkat. Kedua, membahas mengenai peningkatan sarana dan prasarana di sekolah. Apabila fasilitas dari sekolah itu terpenuhi dengan baik maka tingkat keinginan peserta didik untuk belajar menjadi meningkat, karna disitu timbul sebuah kenyamanan. Ketiga, membahas mengenai peran pendidik dalam meningkatkan kualitas pembelajaran melalui sarana dan prasarana. Maksudnya disini yaitu pendidik menggunakan sarana dan prasarana seperti LCD, Komputer, Laboratorium sekolah dan sebagainya yang telah disiapkan oleh pihak sekolah untuk menunjang kegiatan pembelajaran. penggunaan sarana dan prasarana ini menjadi harapan agar peserta didik dapat melaksanakan pembelajaran dengan nyaman dan tidak ketinggalan dengan sekolah yang lain. Ketiga pembahasan ini diharapkan kita dapat mengetahui penggunaan strategi yang tepat untuk meningkatkan kualitas mutu pendidikan terutama di Indonesia

\section{Metode Penelitian}

Artikel ini dibuat menggunakan metode penelitian kualitatif adalah filsafat postpositivisme. Metode ini digunakan untuk meneliti pada kondisi obyek yang alamiah (lawan eksperimen), dimana peneliti sebagai instrument pokok (Sugiyono, 2017). Teknik pengumpulan data dilakukan secara triangulasi (gabungan). Analisis data bersifat induktif/kualitatif. Hasil penelitian kualitatif menekankan makna dari pada generalisasi. Metode kualitatif yang dipakai adalah Narrative research, merupakan penelitian kualitatif dimana peneliti melakukan studi terhadap dua Namrasumber untuk mendapatkan data adanya sarana dan prasarana di SD Al-Ma'shoem. Data tersebut selanjutnya oleh peneliti disusun menjadi laporan naratif kronologis. penelitian yang menghasilkan data deskriptif seperti kata-kata tertulis dan lisan dari orang yang diamati. Penelitian ini dilakukan secara langsung di SD Al- Ma'shoem Bandung, yang terletak di Jl. Raya Cipacing No.22, Cipacing, Jatinangor, Bandung, Jawa Barat 40394. Penelitian ini dilaksanakan pada tanggal 22 September 2021 secara studi dengan Kepala Sekolah dan Direktur Pendidikan di SDIT Al-Ma'shoem.

Teknik pengumpulan data pada penelitian ini dengan cara rekaman suara saat studi dengan narasumber berlangsung, dan juga dokumentasi melalui HP atau Kamera. Langkah langkah yang akan dilakukan dalam analisis data penelitian ini adalah sebagai berikut: 1) Mengelompokan aspek yang diamati melalui pelaksanaan yang direncanakan, mengamati dan mendengarkan saat narasumber menyampaikan materi, 2) Menganalisisdata yang sudah terkumpul saat studi langsung dengan narasumber, 3) Menentukan aspek yang dinilai setiap pengamatannya, 4) Menganalisis hasil belajar siswa dalam ketersediaan sarana dan prasarana di SD Al- Ma'shoem, 5) Mengelompokan aspek-aspek yang diamati berdasarkan ketersediaan sarana dan prasarana di SD AlMa'shoem, 6) Menyimpulkan hasil yang 
Rakanita Dyah Ayu Kinesti, Naily Himmatul Ulya, Laana Nafisatus Suroyya, Fathia Latifah, Eka Vina Rahmawati, Nurul Khoirin Nida, dan Aeni Khasanah

diperoleh pada setiap pengamatan terhadap sarana dan prasarana di SD Al-Ma'shoem.

\section{Hasil dan Pembahasan}

Sumber daya manusia saat ini sangat diperlukan dalam peningkatan kualitas pendidikan. Peningkatan kualitas Sumber Daya Manusia (SDM) dalam berbagai aspek dikehidupan ini merupakan faktor yang menunjang persaingan global yang terjadi di dunia. Jika Sumber Daya Manusia yang kita ciptakan berkualitas maka kita dapat bersaing dengan negara lain secara sehat dan profesional. Peningkatan mutu SDM sangat berkaitan dengan pendidikan. Oleh karena itu, pendidikan menjadi faktor utama dalam peningkatan mutu kualitas SDM. Kualitas pendidikan sangat dipengaruhi oleh beberapa pihak antara lain siswa, orang tua, guru, pemerintah dan sebagainya. Pihak-pihak tersebut saling berkaitan dan sangat diperlukan untuk mewujudkan kualitas pendidikan yang terprogram dan lebih baik.

Strategi peningkatan kualitas pendidikan di Indonesia sangat berkaitan dengan terlaksananya proses pembelajaran di sekolah. Strategi atau kiat-kiat yang digunakan dalam meningkatkan kualitas pembelajaran dilaksanakan dengan memanfaatkan sumber daya dari lembaga yang telah dimiliki. Apabila strategi ini dapat berjalan denganstruktur maka pembelajaran dapat berjalan dengan mudah dan optimal (Solikah, 2015).

Konsep peningkatan kualitas pendidikan merupakan salah satu unsur dari paradigma baru pengelolaan pendidikan tinggi di Indonesia. Paradigma tersebut mengandung atribut pokok yaitu relevan dengan kebutuhan masyarakat pengguna lulusan, suasana akademik (academic atmosphere) yang kondusif dalam penyelenggaraan program studi, adanya komitmen kelembagaan (institusional komitmen) dari para pimpinan dan staf terhadap pengelolaan organisasi yang efektif dan produktif, keberlanjutan (sustainability) program studi, serta efisiensi program secara selektif berdasarkan kelayakan dan kecukupan. Dimensi-dimensi tersebut mempunyai kedudukan dan fungsi yang sangat strategis untuk merancang dan mengembangkan usaha penyelenggaraan pendidikan yang berorientasi kualitas pada masa yang akan datang.

Dari sisi guru, kualitas dapat dilihat dari seberapa optimal guru mampu memfasilitasi proses belajar siswa. Menurut Djemari Mardapi bahwa setiap tenaga pengajar memiliki tanggung jawab (Danumiharja, 2014) terhadap tingkat keberhasilan siswa belajar dan keberhasilan guru mengajar. Sementara itu dari sudut kurikulum dan bahan belajar kualitas dapat dilihat dari seberapa luwes dan relevan kurikulum dan bahan belajar mampu menyediakan aneka stimuli dan fasilitas belajar secara berdiversifikasi. Dari aspek iklim pembelajaran, kualitas dapat dilihat dari seberapa besar suasana belajar mendukung terciptanya kegiatan pembelajaran yang menarik, menantang, menyenangkan dan bermakna bagi pembentukan profesionalitas kependidikan.

Dari sisi media belajar kualitas dapat dilihat dari seberapa efektif media belajar digunakan oleh guru untuk meningkatkan intensitas belajar siswa. Dari sudut fasilitas belajar kualitas dapat dilihat dari seberapa kontributif fasilitas fisik terhadap terciptanya situasi belajar yang aman dan nyaman. Sedangkan dari aspek materi, kualitas dapat dilihat dari kesesuainnya dengan tujuan dan kompetensi yang harus dikuasi siswa. Oleh karena itu kualitas pembelajaran secara operasional dapat diartikan sebagai intensitas keterkaitan sistemik dan sinergis guru, mahasiswa, kurikulum dan bahan ajar, media, fasilitas, dan system pembelajaran dalam menghasilkan proses dan hasil belajar yang optimal sesuai dengan tuntutan kurikuler.

Secara konseptual kualitas perlu diperlakukan (Zainuddin, 2005) sebagai dimensi kriteria yang berfungsi sebagai tolok 
ukur dalam kegiatan pengembangan profesi, baik yang berkaitan dengan usaha penyelenggaraan lembaga pendidikan maupun kegiatan pembelajaran di kelas. Hal ini diperlukan karena beberapa alasan antara lain : Pertama, Lembaga pendidikan akan berkembang secara konsisten dan mampu bersaing di era informasi dan globalisasi dengan meletakan aspek kualitas secara sadar dalam kegiatan pendidikan dan pembelajaran.Kedua, Kualitas perlu diperhatikan dan dikaji secara terus menerus, karena substansi kualitas pada dasarnya terus berkembang secara interaktif dengan tuntutan kebutuhan masyarakat dan perkembangan teknologi. Ketiga, Aspek kualitas perlu mendapat perhatian karena terkait bukan saja pada kegiatan sivitas akademika dalam lingkungan kampus/sekolah, tetapi juga pengguna lain di luar kampus/sekolah sebagai "Stake-holders". Keempat, Suatu bangsa akan mampu bersaing dalam percaturan internasional jika bangsa tersebut memiliki keunggulan (Excellence) yang diakui oleh bangsa-bangsa lain. Kelima, Kesejahteraan masyarakat dan/atau bangsa akan terwujud jika pendidikan dibangun atas dasar keadilan sebagai bentuk tanggung jawab sosial masyarakat bangsa yang bersangkutan.

Secara kasat mata indikator kualitas pembelajaran dapat dilihat antara lain dari perilaku pembelajaran guru, perilaku dan dampak belajar siswa, iklim pembelajaran, materi pembelajaran, media pembelajaran, dan sistem pembelajaran.

Untuk mencapai kualitas pembelajaran dapat dikembangkan antara lain menggunakan (Pandiangan, 2019) strategi Pertama, Perlu dikembangkan berbagai fasilitas kelembagaan dalam membangun sikap, semangat, dan budaya perubahan. Kedua, Peningkatan kemampuan pembelajaran para guru dapat dilakukan melalui berbagai kegiatan profesional secara periodik dan berkelanjutan, misalnya sekali dalam setiap semester yang dilaksanakan oleh masing-masing lembaga pendidikan sebelum awal setiap semester dimulai. Ketiga, Peningkatan kemampuan pembimbingan profesional siswa melalui berbagai kegiatan profesional di sekolah secara periodik, misalnya sekali setiap tahun yang dilaksanakan oleh lembaga pendidikan bekerja sama dengan dinas pendidikan setempat. Keempat, Peningkatan kualitas pelaksanaan praktek pengalaman lapangan (PPL) di tempat praktek, dengan menggiatkan kegiatan kolaborasi lembaga pendidikan dengan tempat praktek serta menyelenggarakan uji kompetensi profesional siswa pada akhir program pendidikan sebelum mereka dinyatakan lulus. Kolaborasi ini berlaku pula dengan asosiasi profesi lain yang relevan.

Dalam upaya peningkatan kualitas pembelajaran tentunya membutuhkan proses pembelajaran memerlukan metode-metode khusus yang jelas untuk mencapai tujuan pembelajaran yang efektif dan efisien. Metodologi pembelajaran merupakan cara cara dalam melakukan aktivitas antara pendidik dan peserta didik ketika berinteraksi dalam proses belajar. Pendidik perlu mengetahui dan mempelajari metode pengajaran agar dapat menyampaian materi dan dimengerti dengan baik oleh peserta didik. Disini kreatifitas seorang guru di peras sedemikian rupa demi menciptakan proses KBM (kegiatan Belajar Mengajar) yang kerative dan menyenangkan. sebenarnya ada 20 metode pembelajaran yang dapat di lakukan oleh guru agar proses kegiatan Belajar mengajar menjadi lebih menyenangkan, akan tetapi tidak semua metode dapat di gunakan di sekolah mengingat setiap siswa memiliki kelebihan dan kekurangannya masing masing.

Metode mengajar yang umum di laksanakan di sekolah adalah metode ceramah dimana guru menyampaikan informasi secara lisan kepada siswa. Metode ini merupakan metode yang paling praktis dan ekonomis, tidak membutuhkan banyak alat bantu. 
Rakanita Dyah Ayu Kinesti, Naily Himmatul Ulya, Laana Nafisatus Suroyya, Fathia Latifah, Eka Vina Rahmawati, Nurul Khoirin Nida, dan Aeni Khasanah

Metode ini mampu digunakan untuk mengatasi kelangkaan literatur atau sumber rujukan informasi karena daya beli siswa yang diluar jangkauan.Namun meski begitu metode mengajar secara ceramah termasuk metode mengajar konvensional yang dimana sudah tidak efektif dan efisien lagi untuk di gunakan guru dalam mengajar siswanya sehari hari, meski di Al Masoem metode ini masih kadang di gunakan namun tidak di gunakan setiap hari atau setiap pembelajaran, karena metode ini memang sangat terbatas dan memiliki banyak kekurangan namun meski begitu metode ini biasanya di gunakan hanya beberapa menit dalam setiap pembelajaran yang dimana di tambah dengan metode lainnya seperti metode diskusi, metode ceramah tambahan dan lain sebagainya. Metode pembelajaran yang bersifat campuran namun membentuk kreativitas siswa secara penuh dan menuntun siswa agar menjadi pribadi yang berakhlakul kharimah.Karena di Al Masoem sendiri setiap pelajaran di ajarkan oleh guru yang berbeda beda, disini dapat di simpulkan bahwa pemfokusan pelajaran di ajarkan oleh satu guru dalam artian guru Al Masoem jelas profesional di bidang nya masing masing.

Tata cara mengajar Guru Al Masoem pun terbilang unik dan semua juga tergantung dari masing masing guru tersebut, selama itu tidak melanggar kode etik guru dan juga selama itu memang dapat meningkatkan kualitas belajar mengajar dan juga selama tidak melanggar perautran yang ada. Selain itu, guru atau pendidik di SD IT Al Masoem juga menggunakan aplikasi mss, pembelajaran melalui website sekolahnya, dan sebagainya.

Guru Al Masoem juga di tuntut untuk melakukan variasi dalam mengajar, seperti ada beberapa guru yang memperlihatkan video tentang motivasi sebelum belajar, ada juga guru yang mengajak siswanya untuk belajar di luar seperti di perpustakaan atau di tempat fasilitas belajar mengajar AL Masoem, atau ada juga guru yang menggunakan multimedia untuk mengajar dan banyak lagi. Guru $\mathrm{Al}$
Masoem juga terbilang guru yang sangat sangat amat sabar, saya tidak bisa memungkiri bahwa guru AL Masoem terutama untuk tingkat Sekolah Dasar merupakan guru yang memiliki tingkat kesabaran yang tinggi, mengingat siswa Sekolah Dasar masih kecil dan lagi masa masanya, guru SD Al Masoem tidak pernah marah atau menegor secara kasar. Karena itu pula Guru Al Masoem sangat patut di contoh oleh guru sekolah lain yang memang sederajat tingkatannya.

Metode pembelajaran di Al Masoem juga tidak hanya sekedar teori semata, ada beberapa pelajaran yang dilaksanakan secara praktek langsung, seperti IPA dari BIOLOGI, KIMIA dan FISIkA kami memiliki LAB yang memadai dengan berbagai macam fasilitas $\mathrm{di}$ dalam nya. Untuk praktek olah raga juga kami menyediakan berbagai macam lapangan yang langsung di praktikan langsung di pelajaran olah raga dan juga untuk pelajaran komputer, Al Masoem menyediakan 100 lebih komputer dengan spek mempuni demi memaksimalkan potensi siswa di bidang IT tentu saja dengan LAB komputer yang memadai dan nyaman untuk di gunakan. Sebenarnya metode pembelajaran di Al Masoem merupakan metode pembelajaran campuran yang dimana hampir di semua aspek yang dimana metode pembelajaran umum ada kekurangannya maka dengan metode pembelajaran khas Al Masoem semua kekurangan itu di minimalisir sedemikian rupa agar tercipta metode pembelajaran yang variatif dan efisien.

Selain itu, Pengembangan kurikulum dapat didefinisikan sebagai semacam proses langkah demi langkah yang digunakan untuk menciptakan perbaikan positif dalam program pembelajarn yang ditawarkan di sebuah institusi pendidikan. Pendekatan dan perspektif tentang penyelenggaraan sudah berubah di masa modern ini; dan kebutuhan kualitas pendidikan mempengaruhi kurikulum. Teknik dan strategi pengajaran yang inovatif, seperti pembelajaran transformatif atau pembelajaran campuran (blended-learning), 
terus-menerus dirancang untuk meningkatkan pengalaman belajar siswa yang semakin maju dan baik.

Dampaknya, pemerintah secara umum dan institusi Pendidikan khususnya harus memiliki rencana untuk menghadapi pergeseran ini dan kemudian dapat menerapkannya dalam kurikulum yang baru. Hal inilah yang medorong adanya konsep kurikulum merdeka belajar yang dicanangkan oleh kemendikbud. Merdeka belajar bermakna kemerdekaan belajar, yakni memberikan kesempatan belajar sebebas-bebasnya dan senyaman-nyamannya kepada anak didik untuk belajar dengan tenang, santai dan gembira tanpa stres dan tekanan dengan memperhatikan bakat alami yang mereka punyai, tanpa memaksa mereka mempelajari atau menguasai suatu bidang pengetahuan di luar hobi dan kemampuan mereka,sehingga masing-masing mereka mempunyai portofolio yang sesuai dengan kegemarannya.

Tidak terkecuali yang dilakukan oleh Yayasan Al Masoem Bandung dalam merealisasikan konsep kurikulum merdeka belajar ini. Kurikulum ini mengadaptasi konten pembelajaran (dari standar eksternal dan tujuan lokal) kemudian membentuknya menjadi rencana melakukan pengajaran dan pembelajaran yang efektif. Dengan demikian, kurikulum ini lebih dari sekadar wacana untuk meningkatkan kualitas pelajar, khususnya di Indonesia.

Pada dasarnya sistem itu dibuat ketika dijalankan dengan benar maka tujuan dari sistem itu sendiri akan tercapai, perlu penegasan dalam menjalankan revolusi mental bagi tiap-tiap orang yang di pertanggungjawabkan untuk menjalankan peningkatan kualitas pendidikan itu sendiri dan butuh penataan yang baik secara kompleks hingga ke daerah-daerah sehingga pendidikan itu sama tupoksinya di konsumsi oleh masyarakat.

Dalam mendukung program yang dicanangkan oleh pemerintah, Yayasan Al
Masoem Bandung senantiasa mendukung dan memfasiltasi agar semua siswa yang mengenyam Pendidikan di sekolah-sekolah Al Masoem memperoleh Pendidikan yang terstandarisasi dan juga modern sesuai dengan perkembangan Pendidikan di Indonesia.

Dalam merealisasikan konsep merdeka belajar, Yayasan Al Masoem Bandung kini berinovasi dengan mengembangkan berbagai macam kerjasama dengan pihak eksternal guna mendukung kemajuan para siswanya dalam memperoleh Pendidikan yang formal maupun non-formal. Hal ini juga terkait dengan bekal para siswa di masa depan ketika mereka melanjutkan ke jenjang sekolah yang lebih tinggi.

Perencanaan menggambarkan suatu prosedur yang berkesinambungan yang di dalamnya meliputi dua aspek, yakni formulasi dan tindak lanjutnya. Perencanaan bisa digunakan sebagai pengatur dan perbaikan dalam jalannya suatu kegiatan, sebab itu sifat rencana ialah untuk penuntun dalam pelakasanaan suatu kegiatan (Sutarto, 2000). Perencanaan bisa dikerjakan pada pelbagai bidang, akan tetapi tidak semua rencana termasuk perencanaan pembangunan terikat dalam rasionalitas pembangunan oleh sebab itu pemerintah bertindak sebagai pendorong pembangunan, ini termasuk dengan uraian perencanaan yang merupakan upaya institusi public guna merancang arah kebijakan pembangunan yang wajib dikerjakan disuatu daerah baik di Negara ataupun daerah yang berdasarkan kemajuan dan kekurangan yang daaerah tersebut miliki.

Keterbatasan sarana dan prasarana yang ada di sekolah tentu saja berpengaruh pada nilai atau hasil belajar pesera didik. Dengan artian lain prosedur pelaksanaan kegiatan belajar mengajar di sekolah juga problematika dalam pembelajaran tidak hanya dihadapi bagi pendidik yang bertaut, namun didorong pula oleh adanya dan kelengkapan sarana dan prasarana pendidikan. 
Rakanita Dyah Ayu Kinesti, Naily Himmatul Ulya, Laana Nafisatus Suroyya, Fathia Latifah, Eka Vina Rahmawati, Nurul Khoirin Nida, dan Aeni Khasanah

Semakin bertumbuhnya ilmu pengetahuan dan teknologi sehingga dalam kegiatan pendidikan dibutuhkan upaya eksploitasi alat peraga dan alat praktik guna sarana demi membangkitkan motivasi murid dalam belajar serta penghematan waktu. Demi mendapatkan hasil belajar yang sinkron sama tujuan yang sudah dirancang sehingga proses pendidikan harus sungguh-sungguh diusahakan dengan maksimal .

Sebuah perencanaan merupakan langkah paling dasar atau langkah awal dalam menentukan sebuah tujuan dan mendapat hasil optimal (Indrawan, 2015) . Perencanaan yang baik akan mendapatkan hasil yang baik pula. Dan sebaliknya sebuah perencanaan yang kurang matang dalam pertimbangannya akan pula menghasilkan hasil yang kurang memuaskan. Oleh karena itu sebuah perencanaan sangat penting dilakukan karena sangat mempengaruhi hasil akhirnya nanti. Perencanaan sarana dan prasarana di sekolah merupakan salah satu langkah sekolah dalam meningkatkan kualitas sekolah dan kualitas pembelajaran dalam sekolah tersebut. Banyak sekolah berlomba lomba untuk selalu menguprade dan meningkatkan sarana dan prasarana mereka agar dapat meningkatkan kualitas sekolah dan pendidikan yang terdapat di sekolah tersebut. Semakin lengkap dan banyaknya fasilitas sarana dan prasarana didalam sekolah tersebut maka akan semakin baik pula kualitas yang ada. Banyak hal yang harus diperhatikan dalam mempersiapkan sarana dan prasarana sekolah untuk meningkatkan mutu sekolah baik pembelajaran ataupun para siswanya. Dalam perencanaan peningkatan sekolah meliputi perencanaan, pengadaan, inventarisasi, penataan, dan pemeliharaan.

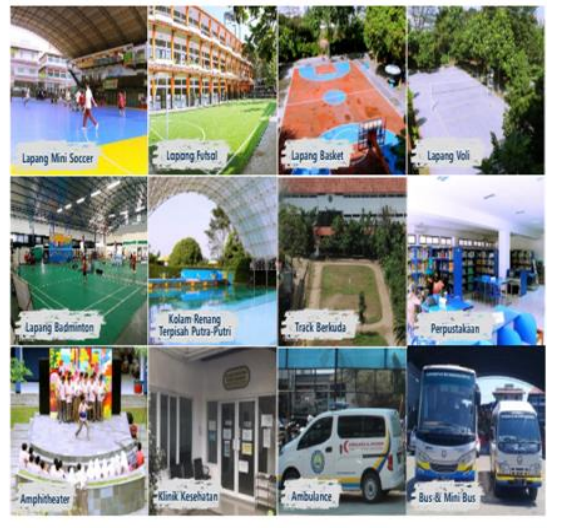

Sumber

:https://www.almasoem.sch.id/tm_images/edit orimg/1231.png

Perencanaan sarana prasarana yang terdapat di SD Al-Ma'soem sangatlah baik terbukti adanya banyak sarna prasarana yang ada disekolah tersebut. Fasilitas sarana dan prasarana yang ada juga sangat jelas membantu para siswa dalam menjalankan kegiatan pembelajaran disekolah. Semua sarana dan prasarana yang ada di SD AlMa'soem menggambarkan bahwa perencanaan yang dipertimbangkan oleh pihak sekolah sangat tertata dan sesuai dengan target. Perencanaan yang dibuat oleh pihak sekolah di SD Al-Ma'soem sangat berdampak pada kualitas pembelajaran para peserta didik. Dengan perencanaan yang matang dan mempertimbangan segala aspek yang ada maka akan menghasilkan hasil yang sempurna pula. Dalam perencanaan harus mempertimbangkan banyak aspek agar semua sarana dan prasarana yang ada dapat berguna dengan baik sesuai dengan fungsinya masing masing.

Sarana merupakan sebuah perlengkapan pada kegiatan pembelajaran. Di SD Al-Ma'soem juga merencanakan sarana yang baik bagi para peserta didiknya. Di SD Al-Ma'soem menyediakan sarana yang biasanya memang wajib ada di sekolah sekolah dasar lainnya. Sarana yang terdapat seperti buku pembelajaran, layar proyektor tiap kelas, sound sistem agar pembelajran dikelas lebih jelas jika guru mengajar dengan 
presentasi di layar proyektor, lalu terdapat pula kursi yang nyaman, lalu terdapat meja, terdapat pula televisi dan juga tersedianya internet atau wi-fi. Lalu terdapat pula pojok baca SD atau bisa dikatakan perpustakaan mini di pojok kelas Sd. Hal itu semua direncanakan dan di maksimalkan agar kegiatan belajar mengajar yang ada semakin berkualitas lagi dan semakin baik lagi. Sarana merupakan salah satu hal yang sangat penting untuk direncanakan karena dengan adanya sarana yang baik maka akan sangat membantu sekali kegiatan belaja mengajar yang ada. Dan yang istimewa dari SD Al-Ma'soem adalah dengan adanya dua jenis buku yaitu tematik dan yang tidak tematik. Dalam pengembangan sarananya di SD Al-Ma'soem pihak sekolah menyediakan buku yang tidak tematik juga karena isi materi didalamnya yang lebih lengkap dan lebih luas. Jadi para peserta didik mempunyai dua gambaran antara buku tematik dan yang tidak dengan inti materi yang sama tetapi dengan kelengkapan isi didalamnya yang berbeda. Dan terdapat pula sarana transportasi untuk peserta didik bis sekolah, mini bus, ambulance,dan Mobil jemputan SD. Dan ini merupakan salah satu perencanaan peningkatan yang baik karena dapat membuat para peserta didiknya lebih bisa banyak mengetahui tentang materi materi pembelajaran yang ada sesuai dengan kurikulum yang sudah ditentukan.

Prasarana merupakan sebuah fasilitas pokok yang ada untuk dapat menunjang sarana yang telah disediakan. Prasarana merupakan hal yang penting untuk para peserta didik dapat melakukan pembelajaran dengan rasa aman dan nyaman. SD AlMa'soem juga menyediakan fasilitas prasarana yang bisa dibilang sangat legkap. Banyak sekali prasarana yang disediakan untuk meningkatkan kualitas pembelajaran yang ada. Dan di Al-Ma'soem menyediakan prasarana seperti ruang kelas ber AC, kamar mandi, Dome, Kolam renang terpisah antara peserta didik putra dan peserta didik putri,
Lapang basket, Lapang voli, Lapang mini soccer, Lapang futsal (rumput sintetis), Lapang badminton, Laboratorium Biologi, Fisika dan Kimia, Laboratorium Komputer, Laboratorium Bahasa, Amphitheater, Ruang Konselor, Ruang seminar, Ruang Multimedia Terintergasi, Poliklinik, Perpustakaan yang terintegrasi, Kantin representatif, Minimarket, Wall climbing, lapangan panahan, lapangan berkuda, dan terdapat pula ATM centre. Dan prasarana yang terdapat disekolah tersebut merupakan sebuah prasarana yang sangat lengkap dan hal tersebut sangat mendukung dalam hal peningkatan pembelajaran para peserta didik. Dengan adanya prasarana yang sangat lengkap tersebut dapat mendorong kualitas pembelajaran menjadi semakin baik lagi. Perencanaan prasarana yang sangat banyak tersebut tentu membutuhkan perencanaan yang sangat matang dan memikirkan segala sisi. Dan terbukti dengan adanya peningkatan sarana dan prasarana yang ada sekolah di SD Al-Ma'soem menjadi sekolah yang sangat unggul dan baik dalam segla sisi. Dan sekolah tersebut berhasil menerapkan sebuah perencanaan dibidang sarana dan prasarana dengan banyaknya fasilitas yang disediakan serta dengan banyaknya prestasi para peserta didik itu dapat membuktikan bahwa perencanaan yang dilakukan dengan cara yang matang dan efektif.

Sudah seharusnya sekolah menyediakan dan membuat fasilitas sekolah dengan sebaik mungkin. Karena dengan pengadaan sarana dan prasarana yang baik maka akan tercapai pula kualitas pembelajaran yang diharapkan. Pengadaan sarana dan prasarana dapat dikatakan sebagai menyiapkan atau menyediakan segala fasilitas yang berhubungan dengan kegiatan belajar mengajar baik dari segi sarana maupun dari segi prasarana. Di SD Al-Ma'soem sarana dan prasarana disediakan oleh pihak sekolah. Dan sarana dan prasarana yang disediakan merupakan sarana dan prasarana yang 
Rakanita Dyah Ayu Kinesti, Naily Himmatul Ulya, Laana Nafisatus Suroyya, Fathia Latifah, Eka Vina Rahmawati, Nurul Khoirin Nida, dan Aeni Khasanah

bermanfaat bagi para peserta didik baik untuk pembelajaran maupun untuk ekstrakulikuler yang ada. Semua sarana dan prasarana di SD Al-Ma'soem dapat dikatakan sebagai sarana dan prasarana yang baik dan lengkap. Karena disana menyediakan berbagai sarana dan prasarana yang sangat membantu para peserta didik dalam kegiatan pembelajaran maupun luar pembelajaran. Dengan pengadaan sarana dan prasaran maka kegiatan pembelajaran akan berlangsung dengan baik. Dan dalam pengadaan sarana dan prasarana pasti pihak sekolah telah mempertimbangkan banyak hal mulai dari keefektifan sampai dengan respon balik para peserta didik. Semua itu pasti telah dipikirkan matang matang oleh pihak sekolah. Dan dengan adanya pengadaan sarana dan prasarana dari pihak sekolah maka akan membuat banyak siswa yang menjadi nyaman karena dengan banyak fasilitas yang mereka dapatkan akan sangat mempermudah kegiatan belajar mengajar para peserta didik. Oleh karena itu pengadaan sarana dan prasarana sangat penting untuk diadakan pihak sekolah agar tercapainya kualitas pembelajaran yang semakin baik lagi dan semakin berkembang. Semua peserta didik akan merasa dipermudah dengan adanya pengadaan sarana prasarana yang mumpuni oleh pihak sekolah .

Iventarisasi merupakan sebuah kegiatan pendistribusian sarana dan prasarana atau bisa dikatakan penggunaan sarana dan prasarana yang sudah disediakan. Dan di SD AlMa'soem sarana dan prasarana sekolah di iventarisasikan kepada para masyarakat sekolah. Dengan diinvetarisasikan kepada masyarakat sekolah maka akan membuat pelaksanaan kegiatan belajar mengajar menjadi lebih mudah dan nyaman. Sarana dan prasarana sangat penting bagi para masyarakat sekolah karena dengan adanya sarana prasarana yang ada maka akan membuat semua kegiatan menjadi lebih baik dan terkendali. Semua sarana dan prasarana yang ada dapat dimanfaatkan oleh para masyarakat sekolah dengan sebaik mungkin agar mempermudah dan memperlancar kegiatan yang ada. Inventarisasi kepada masyarakat merupakan salah satu cara menyamaratakan agar dapat mencapai tujuan bersama dengan optimal.

Di dalam sarana dan prasarana penataan merupakan hal yang perlu diperhatikan agar semua sarana dan prasarana menjadi efektif dan bermanfaat bagi para peserta didik. Dengan penataan sarana dan prasarana di SD Al-Ma'soem maka akan membuat semua kegiatan yang berhubungan dengan sarana prasarana menjadi lebih tertata dan juga lebih sistematis. Penataan sarana prasarana yang baik juga akan sangat berpengaruh kepada feedback para peserta didik yang menggunakannya. Penataan yang tepat akan menghasilkan sebuah hasil yang efektif, tepat dan juga optimal. Oleh karena itu penataan sarana prasarana harus ditata dan dilakukan dengan baik, sistematis dan tepat.

Pemeliharaan sarana prasarana juga penting dalam perencanaan peningkatan sarana prasarana. Dengan pemeliharaan yang dilakukan secara rutin maka akan membuat sarana dan prasarana yang ada menjadi lebih terjaga dan terawat. Di SD Al-Ma'soem walaupun sekolah libur semua sarana dan prasarana sekolah yang mendukung pembelajaran akan tetap dirawat. Hal ini dilakukan agar pada saat peserta didik atau masyarakat sekolah masuk sekolah dapat menggunakan sarana dan prasarana dengan nyaman dan dapat memanfaatkannya sebagaimana mestinya. Dengan adanya pemeliharaan sarana prasarana yang baik maka akan menjaga sarana prasarana pembelajaran tersebut.

Kualitas pendidikan merupakan salah satu isu sentral, dan yang sering menjadi sorotan adalah pendidik. Walaupun diketahui bahwa berbagai macam komponen turut menjadi pengaruh, seperti : kurikulum, siswa, dan media pembelajaran. Hal ini sangat dipungkiri bahwa guru merupakan perencana sekaligus pelaksana pembelajaran, sehingga 
guru selalu dituntut dalam meningkatkan kinerja demi terciptanya proses pembelajaran yang efektif agar bisa mencapai tujuan pendidikan nasional. Guru merupakan peran utama dalam pelaksanaan pembelajaran baik sebagai pengajar, pengelola, dan perananperanan lain (Idzhar, 2016).

Keberhasilan program pendidikan melalui proses pembelajaran sangat dipengaruhi oleh banyak faktor, salah satu diantaranya adalah tersedianya sarana dan prasarana pendidikan yang memadai disertai pemanfaatan dan pengelolaan secara ideal. Sarana dan prasarana pendidikan merupakan salah satu sumber daya yang penting dan utama dalam menunjang proses pembelajaran di sekolah, untuk itu perlu dilakukan peningkatan dalam pendayagunaan dan pengelolaannya, agar tujuan yang diharapkan dapat tercapai. Fasilitas pendidikan merupakan salah satu faktor penentu keberhasilan pendidikan. Kelengkapan dan ketersediaan fasilitas pendidikan di sekolah sangat berpengaruh terhadap keefektifan dan kelancaran pembelajaran di dalam kelas.

Semua fasilitas atau sarana dan prasarana sekolah haruslah dikelola dengan baik agar keberadaan sarana dan prasarana tersebut dapat menunjang proses pembelajaran dan digunakan sesuai kebutuhan, sehingga pembelajaran di kelas dapat berjalan lancar dan tujuan pendidikan dapat terwujud. Dalam kegiatan pembelajaran sarana dan prasarana sangat diperlukan dalam rangka menunjang kelancaran proses kegiatannya, sehingga pengelolaan sarana dan prasarana sangat diperlukan oleh setiap instansi terutama sekolah. Sarana dan prasarana pendidikan merupakan salah satu sumber daya yang penting dalam menunjang prosess pembelajaran di sekolah. Keberhasilan program pendidikan di sekolah sangat dipengaruhi oleh kondisi sarana dan prasarana pendidikan yang dimiliki sekolah dan oleh optimalisasi pengelolaan dan pemanfaatannya.
Sarana dan prasarana pendidikan juga digunakan untuk mempermudah pemahaman siswa tetang materi yang disampaikan dengan menggunakan sarana dan prasarana pendidikan yang tepat dalam program kerja mengajar menjadi lebih efektif dan efesien. Dengan adanya sarana dan prasarana pendidikan kegiatan belajar mengajar akan menjadi lebih bermakna dan berkualitas dan menyenangkan.

Sarana pendidikan merupakan sarana penunjang bagi belangsungnya proses belajar mengajar. Hal ini merupakan faktor yang harus diperhatikan oleh sebuah lembaga pendidikan karena mempengaruhi kelangsungan proses belajar mengajar di sekolah. Sarana dan prasarana sangat diperlukan untuk menunjang proses belajar mengajar, agar siswa lebih berminat dan mudah menerima penjelasan dari pendidik (Sinta, 2019)._ Apabila sarana dan prasarana yang disediakan kurang, maka dapat mempengaruhi minat siswa untuk mengikuti proses belajar mengajar. Jika siswa memiliki minat dalam mengikuti proses belajar mengajar, maka faktor tersebut dapat meningkatkan prestasi belajar siswa (Kartika et al., 2019).

Sarana pendidikan adalah peralatan dan perlengkapan yang secara langsung dipergunakan dan menunjang proses pendidikan khususnya proses belajar mengajar. Contohnya: gedung, ruang kelas, meja, kursi.

"Sarana pendidikan adalah semua fasilitas yang diperlukan dalam proses belajar mengajar baik yang bergerak maupun tidak bergerak agar pencapaian tujuan pendidikan dapat berjalan dengan lancer, teratur, efektif dan efisien".

Menurut keputusan menteri P dan K No 079/ 1975, sarana pendididkan terdiri dari 3 kelompok besar yaitu : (1) Bangunan dan perabot sekolah, (2) Alat pelajaran yang terdiri dari pembukuan, alat-alat peraga dan laboratorium, (3) Media pendidikan yang 
Rakanita Dyah Ayu Kinesti, Naily Himmatul Ulya, Laana Nafisatus Suroyya, Fathia Latifah, Eka Vina Rahmawati, Nurul Khoirin Nida, dan Aeni Khasanah

dapat di kelompokkan menjadi audiovisual yang menggunakan alat penampil dan media yang tidak menggunaakan alat penampil.

Sedangkan Prasarana pendidikan adalah fasilitas yang secara tidak langsung menunjang jalannya proses pendidikan, tetapi dapat dimanfaatkan untuk proses belajar. Contohnya: taman sekolah untuk pengajaran biologi.

Menurut Peraturan Mendiknas Nomor 24 Tahun 2007 tentang Standar Sarana dan Prasarana SD/MI disebutkan bahwa; Lahan untuk SD/MI memenuhi ketentuan rasio minimum luas lahan terhadap peserta didik, Luas lahan yang dimaksud adalah luas lahan yang dapat digunakan secara efektif untuk membangun prasarana sekolah berupa bangunan gedung dan tempat bermain/berolahraga, Lahan terhindar potensi bahaya yang mengancam kesehatan dan keselamatan jiwa, serta memiliki akses untuk penyelamatan dalam keadaan darurat, Lahan terhidar dari gangguan-gangguan pencemaran air, pencemaran udara, dan kebisingan. Yang kedua, Bangunan gedung; Bangunan gedung memenuhi ketentuan rasio minimum luas lantai terhadap peserta didik, Bangunan gedung memenuhi ketentuan tata bangunan, Bangunan gedung memenuhi persyaratan keselamatan, kesehatan, kenyamanan, dan keamanan, Bangunan gedung menyediakan fasilitas dan aksesibilitas yang mudah, aman, dan nyaman termasuk bagi penyandang cacat, Bangunan gedung dilengkapi sistem keamanan (Mardita, 2019).

Suksesnya pembelajaran yang ada di sekolah ditunjang dengan adanya sarana dan prasarana yang tersedia, namun sarana dan prasarana ini harus dikelola dengan baik demi kelancaran proses pembelajaran. Selain itu, berjalannya pembelajaran tidak terlepas dari peran seorang tenaga pendidik atau guru, guru merupakan seseorang yang bertugas untuk mengajar, mendidik, membimbing peserta didiknya, karena hanya gurulah yang bisa dan mampu memberikan pembelajaran, bimbingan, dan pendidikan kepada peserta didik dalam sebuah lembaga pendidikan atau sekolah. Pendidikan akan tercapai dengan adanya proses pembelajaran yang ditentukan oleh guru dan peserta didik agar terciptanya kelancaran interaksi antara guru dan peserta didik. Seorang guru diharapkan memiliki karakteristik kepribadian yang ideal dan sesuai dengan syarat psikologis pedagosis dan haruslah memiliki profesionalisme keguruan.

Karakteristik kompetensi dan juga profesionalisme keguruan yang dimiliki guru mempunyai tujuan untuk menjadi guru yang memiliki nilai tambah yang berbeda dalam pandangan masyarakat, lebih dihargai dan dihormati, lebih disegani dan tidak dianggap remeh oleh sebagian masyarakat terlebih oleh peserta didiknya. Terlepas dari itu semua, guru merupakan pendidik dan pengajar yang menjadi faktor penentu kesuksesan dalam meningkatkan kualitas pendidikan. Selain itu guru juga dituntut untuk mamapu membangkitkan motivasi dan semangat belajar para peserta didiknya agar pembelajaran yang direncanakan dapat terwujud secara optimal (Hanafi, 2018)

\section{Kesimpulan}

Peran guru dalam mendidik dan mengembangkan peserta didik itu sangat tinggi, karena gurulah yang akan menjalankan pembelajaran untuk siswa. Oleh karena itu guru dituntut untuk kreatif, inovatif, dan memiliki wawasan yang luas. Seperti guru di SD Al-Ma'soem yang semua gurunya memiliki tingkat kreatifitas, inovatif, dan wawasan yang luas. Di SD Al-Ma'soem banyak guru yang melakukan variasi dalam mengajar, jadi guru tidak hanya mengadakan proses pembelajaran di dalam kelas tetapi juga membawa siswa dan siswinya belajar di luar kelas dengan memanfaatkan sarana dan prasarana di SD Al-Ma'soem seperti belajar di BSG, DPR, ataupun di perpustakaan milik AlMa'soem. Atau terkadang juga guru mengajak 
siswa dan siswinya belajar di lab, seperti lab komputer, lab ipa, dan lab bahasa.

Pembelajaran juga akan berjalan dengan baik jika guru menguasai materi yang diajarkan oleh karena itu guru di SD AlMa'soem mengajar sesuai dengan bidangnya seperti guru Bahasa Inggris akan mengajar Bahasa Inggris. Dan apabila guru pelajaran tertentu berhalangan hadir maka akan ada guru pengganti yang sama profesionalnya dengan guru yang berhalangan hadir. Sehingga apa yang diajarkan oleh guru menjadi lebih maksimal karena tidak ada guru Bahasa Inggris yang mengajar Penjaskes, oleh karena itu juga di SD Al-Ma'soem tidak ada jam kosong dan waktu belajar digunakan sebaik mungkin.

Demi terciptanya proses pembelajaran yang maksimal SD Al-Ma'soem sangat memperhatikan kenyamanan dan kebutuhan siswa-siswinya dalam belajar, salah satunya adalah ruang kelas atau ruang belajar. Ruang kenal di SD Al-Ma'soem diciptakan dengan nyaman dan menyenangkan. Karena proses pembelajaran akan berjalan maksimal jika kelas yang dipakai bersih, nyaman dan tertata rapi. Di sini peran guru adalah mengajak siswa-siswinya untuk selalu menjaga kebersihan dan kerapian kelas. Seperti mengajarkan untuk membuang sampah ke tempat sampa dan mengembalikan barang ke tempat semula. Selain itu juga dalam meningkatkan penataan ruang kelas, pihak sekolah SD Al-Ma'soem sering mengadakan lomba kebersihan kelas. Perlombaan antar kelas ini akan memacu siswa untuk menciptakan suasana kelas yang nyaman, bersih dan rapi.

Gaya guru dalam mengajar juga akan mempengaruhi kualitas pembelajaran, guru yang simpatik dan demokratis lebih mudah menciptakan suasana kelas yang kondusif. Karena siswa merasa bebas, dihargai dan tidak takut salah ketika menjawab ataupun mengajukan pertanyaan. Penggunaan media dan metode belajar juga menentukan kualitas pembelajaran, seperti penggunaan media audio visual saat menerangkan pembelajaran akan membuat siswa lebih mudah paham atau penggunaan metode belajar yang berbedabeda sehingga dalam proses belajar-mengajar siswa tidak bosan.

Peran guru yang lainnya adalah sebagai panutan bagi peserta didik, karenanya guru harus memiliki tanggung jawab, wibawa, mandiri dan disiplin. Guru-guru di SD AlMa'soem juga demikian, para guru selalu menjaga penampilan agar terlihat bersih dan rapi agar peserta didik ikut mencontohnya. Selain itu guru juga berperan sebagai pembimbing, baik membimbing selama proses pembelajaran di luar kelas seperti mengajarkan cara berenang, bermain voli, basket, ataupun pembelajaran di dalam kelas, lab dan perpustakaan. Guru juga berperan untuk membimbing kreativitas, emosional, dan spiritual peserta didik.

Pentingnya peran guru dalam meningkatkan kualitas pembelajaran melalui sarana dan prasarana di SD Al-Ma'soem tidak akan tewujud jika peserta didik tidak diajak berkolaborasi dalam proses pembelajaran, oleh karenanya guru juga memiliki peran untuk mengajak siswa belajar dengan berbagai model pembelajaran seperti model jigsaw, talking stick, atau model-model lain yang melibatkan siswa untuk aktif selama proses pembelajaran berlangsung. Selain itu karena sarana dan prasarana di SD Al-Ma'soem yang memadai, maka guru juga berperan untuk memanfaatkannya ketika proses pembelajaran. Dengan demikian kualitas pembelajaran akan meningkat.

\section{Bibliografi}

Danumiharja, M. (2014). Profesi Tenaga Kependidikan. Deepublish. Google Scholar

Hanafi, H. (2018). Profesionalisme guru dalam pengelolaan kegiatan pembelajaran di sekolah. Deepublish. 
Rakanita Dyah Ayu Kinesti, Naily Himmatul Ulya, Laana Nafisatus Suroyya, Fathia Latifah, Eka Vina Rahmawati, Nurul Khoirin Nida, dan Aeni Khasanah

Google Scholar

Idzhar, A. (2016). Peranan guru dalam meningkatkan motivasi belajar siswa. Jurnal Office, 2(2), 221-228. Google Scholar

Indrawan, I. (2015). Pengantar manajemen sarana dan prasarana sekolah. Deepublish. Google Scholar

Kartika, S., Husni, H., \& Millah, S. (2019). Pengaruh Kualitas Sarana Dan Prasarana Terhadap Minat Belajar Siswa Dalam Pembelajaran Pendidikan Agama Islam. Jurnal Penelitian Pendidikan Islam, [SL], 7(1), 113-126. Google Scholar

Mardita, N. (2019). Pengelolaan Sarana Dan Prasarana Pendidikan Untuk Meningkatkan Kualitas Pembelajaran. Google Scholar

Pandiangan, A. P. B. (2019). Penelitian Tindakan Kelas: Sebagai Upaya Peningkatan Kualitas Pembelajaran, Profesionalisme Guru Dan Kompetensi Belajar Siswa. Deepublish. Google Scholar

Shobri, M. (2017). Strategi Meningkatkan Mutu Pendidikan di Madrasah Aliyah Hasan Jufri. CENDEKIA: Jurnal Studi Keislaman, 3(1), 11-26. Google Scholar
Sinta, I. M. (2019). Manajemen Sarana dan Prasarana. Jurnal Isema: Islamic Educational Management, 4(1), 77-92. Google Scholar

Solikah, A. (2015). Strategi Peningkatan Mutu Pembelajaran Pada Sekolah Unggulan: Studi Multi Situs Di MI Darul Muta'Alimin Frateran 1 Kota Kediri. Deepublish. Google Scholar

Sugiyono. (2017). MetodePenelitian Kuantitatif, Kualitatif dan R\&D. Bandung: PT Alfabet. In Sugiyono. (2017). MetodePenelitian Kuantitatif, Kualitatif dan R\&D. Bandung: $P T$ Alfabet. Google Scholar

Sutarto. (2000). Dasar-dasar organisasi. Gadjah Mada University Press. Google Scholar

Yana, N. (2019). Penerapan Strategi Pembelajaran Everyone Is A Teacher Here Terhadap Hasil Belajar Kelas V MIS Lamgugob Banda Aceh Pada Mata Pelajaran IPS. UIN Ar-Raniry Banda Aceh. Google Scholar

Zainuddin, M. (2005). Strategi Peningkatan Kualitas Pendidikan Tinggi. Google Scholar

\section{Copyright holder :}

Rakanita Dyah Ayu Kinesti, Naily Himmatul Ulya, Laana Nafisatus Suroyya, Fathia Latifah, Eka Vina Rahmawati, Nurul Khoirin Nida, dan Aeni Khasanah (2020).

First publication right :

Action Research Literate

This article is licensed under:

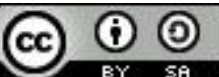

